\title{
Enhancement of Nutritional Quality of Italian Ryegrass Mediated Silage by Supplemented with Lactic Acid Bacteria and Chlorella
}

\author{
Mayakrishnan Vijayakumar, Soundarrajan Ilavenil, Mariadhas Valan Arasu, Min-Woong Jung, Hyung Soo Park, \\ Ji Hea Kim, Young Cheol Lim and Ki Choon Choi* \\ Grassland and Forage Division, National Institute of Animal Science, Rural Development Administration, Seonghwan-Eup, \\ Cheonan-Si, Chungnam, 330-801, Republic of Korea
}

\begin{abstract}
The aim of present study was to improve the quality of silage using lactic acid bacteria (LAB) and chlorella as a supplement. Italian ryegrass (IRG) mediated silage was prepared with lactic acid bacteria (L. plantarum) and different concentration of chlorella. We analyzed the nutritional profiles such as crude protein (CP), acid detergent fiber (ADF) neutral detergent fiber (NDF), total digestible nutrient (TDN) and in-vitro dry matter digestibility (IVDMD), microbial counts and fermentative acids such as lactic acid, acetic acid and butyric acid in the control and experimental silage after three months. It shows increased crude protein content and also maintains the rest of nutritional values as compared with control silage. LAB inoculation with chlorella as supplementation slightly reduced the $\mathrm{pH}$ of the silage. In addition, it increased the fermentative acids production as compared with control silage and inhibits the undesired microbial growth especially fungi in the silage. Therefore, we suggest that LAB inoculation and chlorella supplementation to the IRG mediated silage could be improved the nutritional quality of the silage which is an intrinsic feature for the application in the preparation of animal feeds and functional foods.
\end{abstract}

(Key words : Lactic acid bacteria, Italian ryegrass, Nutritional values, Fermentative acids, Microbial inhibition)

\section{I . INTRODUCTION}

Lactic acid bacteria (LAB) possess different kind of industrial and other applications. It plays an important role in the preservation of moist forages for animals. The basic principle of silage preparation is to store the silage for a long time without loss of their stability and nutritional values required for feeding the animals. The lactic acid bacteria produce the lactic acid which reduced the $\mathrm{pH}$ of silage and inhibits the proliferation of spoilage microorganism's because all most all the microorganisms are more susceptible to low $\mathrm{pH}$. Plant soluble carbohydrates are main substrate for the lactic acid production from the $\mathrm{LAB}$ (McDonald et al., 1991ab). The major carbohydrates found in the forage crops are fructose, glucose, sucrose and frutosanas (Woolford, 1984), among these sucrose and frutosanas are quickly hydrolyzed in their monomers at forage harvest. Microbial inoculants often used as an additive to enhance the fermentation products and preserve the ensiled crops. Most commonly available inoculants are homofermentative lactic acid bacteria such as L. plantarum, E. faecium, $P$. acidilactici and $P$. pentosaceus and hetro fermentative bacteria are also sometimes used as inoculants for silage preparation because it produces the volatile fatty acids which restrict the microbial growth, which are activated upon the aerobic exposure of silage (Weinberg, 2003). Microalgae are prokaryotic or eukaryotic photosynthetic microorganisms which convert sunlight and carbon dioxide to biomass that includes lipids, proteins and carbohydrates (Chisti, 2007) and also it contains pigments and antioxidants (Mata et al., 2010). Therefore, we planned to prepare the IRG mediated silage using $L$. plantarum and chlorella as a supplementation for improvement of nutritional quality of silage.

\footnotetext{
* Corresponding author: Ki Choon Choi, Grassland and forage division, National Institute of Animal Science, RDA, Seonghwan-Eup, Cheonan-Si, Chungnam, 330-801, Republic of Korea. Tel: +82-41-580-6752, Fax: +82-41-580-6779, E-mail: choiwh@korea.kr
} 


\section{П. MATERIALS AND METHODS}

\section{Collection and preparation of silage}

IRG was harvested at flowering stage and packed in an airtight bag after chopping into $1.0 \sim 1.5 \mathrm{~cm}$ pieces. Silage was manufactured with the addition of fermentative additive containing L. plantarum procured from Chung-Mi Bio Co., Korea (CMBC). L. plantarum was dissolved by method of $\mathrm{CMBC}$ and mixed with different concentration $(0.25 \%$ and $0.5 \%$ of weight of fresh crops) of Chlorella additive and then sealed to prevent air flow. Each control (without addition of LAB strain and Chlorella) and each of the samples with strains were prepared in triplicate. Silage were stored in underground and opened after 3 months. The nutritive values, microbial counts and fermentative metabolites were analyzed.

\section{Nutrient composition and analysis}

Acid detergent fiber (ADF) and neutral detergent fiber (NDF) were analyzed according to the method Van Soest et al. (1993). The content and crude protein was quantified by standard procedure (AOAC, 1990). The in vitro dry matter digestibility (IVDMD) was analyzed by method of modified Moore (1970) Total digestible nutrient (TDN) was calculated as follow; 88.9-(ADF\% $\% 0.79)$. Samples were powdered and passed through a $1 \mathrm{~mm}$ sieve prior to analysis.

\section{Enumeration of microbial populations}

Ten grams of wet silage samples were transferred into flasks containing $100 \mathrm{ml}$ of sterile water. Then it was kept in an orbital incubator shaker at $150 \mathrm{rpm}$ for 30 minutes. Followed by, made a tenfold serial dilutions with water according to the method of Miller and Wolin (1974). $100 \mu \mathrm{l}$ of the sample was spread on selective media(Rogosa, and Sharpe agar (Diffco) and Bromocresol purple blue agar medium) for enumeration of LAB incubation under micro aerobic condition at $28 \pm 1{ }^{\circ} \mathrm{C}$ for 4 days. Yeasts and molds were enumerated on $3 \mathrm{M}$ petrifilm(3 $\mathrm{M}$ Microbiology Products, St.Paul, USA), and following aerobic incubation at $28 \pm 1{ }^{\circ} \mathrm{C}$ for 4 days. Fungi were enumerated on Potato
Dextrose agar(PDA) [4 g/L of potato starch (Diffco), $20 \mathrm{~g} / \mathrm{L}$ of starch (Diffco), and $20 \mathrm{~g} / \mathrm{L}$ of agar (Diffco)] following aerobic incubation at $28 \pm 1{ }^{\circ} \mathrm{C}$ for 4 days.

\section{Analyses of fermentation metabolites}

Weighing $20 \mathrm{~g}$ of silage and $80 \mathrm{ml}$ of deionized water into a blender and homogenized for $2 \times 30 \mathrm{sec}$. The homogenate was kept in a refrigerator at $4^{\circ} \mathrm{C}$ until centrifugation (8000 rpm at $4^{\circ} \mathrm{C}$ for $20 \mathrm{~min}$ ). The $\mathrm{pH}$ of the supernatant was measured after centrifugation using a combination electrode. Water extracts were stored at $-20^{\circ} \mathrm{C}$ with and without stabilization with $5 \%$ meta-phosphoric acid (final concentration). Fermentation byproduct lactic acid content was analyzed by HPLC (HP1100 Agilent Co. USA). The levels of acetic acid and butyric acid were analyzed by Gas chromatography (GC-450, Varian Co., USA) (Kristensen et al., 2007).

\section{Statistical analysis}

The experimental results data were statistically analyzed by T-test and two way ANOVA at $p<0.05$ with the help of SPSS 11.5 version software package.

\section{RESULTS}

We investigated the nutritional and quality improvement of IRG silage according to inoculation of lactic acid bacteria and chlorella as a supplement for IRG mediated silage preparation. Chlorella alone supplementation significantly improved the contents of crude protein as compared with control $(p<0.05)$. However, the contents of ADF, NDF, TDN and IVDMD in supplementation of different concentration of chlorella and LAB inoculation were almost similar as compared with control (Table 1).

Table 2 represents the number of microbes in the IRG silage. Supplementation of two different concentration of chlorella and inoculation of LAB significantly increased number of the LAB counts as compared with control $(p<0.05)$. Minimum numbers of yeast colonies were recorded in IRG silage inoculated with both chlorella and LAB. No fungi growth was observed in the prepared silage. 
Table 1. Changes of nutritive value and in vitro dry matter digestibility on Italian ryegrass silage according to inoculation of lactic acid bacteria and chlorella

\begin{tabular}{|c|c|c|c|c|c|c|}
\hline $\mathrm{LAB}$ & $\mathrm{CA}^{3)}$ Con. & $\mathrm{CP}^{4)}(\%)$ & $\mathrm{ADF}^{5)}(\%)$ & $\mathrm{NDF}^{(6)}(\%)$ & IVDMD $^{7}(\%)$ & $\operatorname{TDN}^{8)}(\%)$ \\
\hline \multirow{3}{*}{ NON-in ${ }^{1)}$} & Control & 10.17 & 37.68 & 59.14 & 67.20 & 59.13 \\
\hline & $0.25 \%$ & 11.56 & 34.86 & 58.39 & 67.33 & 61.36 \\
\hline & $0.5 \%$ & 12.84 & 37.16 & 57.94 & 67.23 & 59.54 \\
\hline \multirow{3}{*}{ LAB-in ${ }^{2)}$} & Control & 10.32 & 38.03 & 58.21 & 67.64 & 58.86 \\
\hline & $0.25 \%$ & 11.92 & 39.41 & 65.15 & 66.87 & 57.77 \\
\hline & $0.5 \%$ & 13.63 & 38.20 & 59.36 & 67.21 & 58.72 \\
\hline \multicolumn{7}{|c|}{ Main effect } \\
\hline & -IN & 11.52 & 36.57 & 58.49 & 67.25 & 60.01 \\
\hline & $-\mathrm{IN}$ & 11.96 & 38.55 & 60.91 & 67.24 & 58.45 \\
\hline \multicolumn{7}{|c|}{ Subplot effect } \\
\hline & & $10.25^{\mathrm{c}}$ & 37.86 & 58.68 & 67.42 & 59.00 \\
\hline Chl & $0.25 \%$ & $11.74^{\mathrm{b}}$ & 37.14 & 61.77 & 67.10 & 59.57 \\
\hline $\mathrm{Chl}$ & $0.5 \%$ & $13.24^{\mathrm{a}}$ & 37.68 & 58.65 & 67.22 & 59.13 \\
\hline Main $\times S$ & Interaction & $\mathrm{NS}^{9)}$ & NS & NS & NS & NS \\
\hline
\end{tabular}

Table 2. Changes of microbes on Italian ryegrass silage according to inoculation of lactic acid bacteria and chlorella

\begin{tabular}{|c|c|c|c|c|}
\hline LAB & $\mathrm{CA}^{3)}$ Con. & $\begin{array}{c}\left.\mathrm{LAB}^{4}\right) \\
\left(\times 10^{7} \mathrm{CFU}^{5} / \text { gram }\right) \\
\end{array}$ & $\begin{array}{c}\text { Yeast } \\
\left(\times 10^{4} \mathrm{CFU} / \text { gram }\right) \\
\end{array}$ & $\begin{array}{c}\text { Fungi } \\
\left(\times 10^{4} \mathrm{CFU} / \text { gram }\right) \\
\end{array}$ \\
\hline & Control & 104 & 14.50 & 0.00 \\
\hline \multirow[t]{3}{*}{ NON-in ${ }^{1)}$} & $0.25 \%$ & 91.5 & 0.00 & 0.00 \\
\hline & $0.5 \%$ & 117.5 & 12.00 & 0.00 \\
\hline & Control & 120 & 10.20 & 0.00 \\
\hline \multirow[t]{2}{*}{ LAB-in ${ }^{2)}$} & $0.25 \%$ & 159 & 9.50 & 0.00 \\
\hline & $0.5 \%$ & 166 & 8.50 & 0.00 \\
\hline \multicolumn{5}{|c|}{ Main effect } \\
\hline \multicolumn{2}{|c|}{ NON-IN } & 104.33 & 8.83 & 0.00 \\
\hline \multicolumn{2}{|c|}{ LAB-IN } & 148.33 & 9.40 & 0.00 \\
\hline \multicolumn{5}{|c|}{ Subplot effect } \\
\hline \multicolumn{2}{|c|}{ Control } & $118.50^{\mathrm{b}}$ & $12.35^{\mathrm{a}}$ & 0.00 \\
\hline \multicolumn{2}{|c|}{ Chlorella $0.25 \%$} & $118.75^{\mathrm{b}}$ & $4.75^{\mathrm{b}}$ & 0.00 \\
\hline \multicolumn{2}{|c|}{ Chlorella $0.5 \%$} & $141.75^{\mathrm{a}}$ & $10.25^{\mathrm{ab}}$ & 0.00 \\
\hline \multicolumn{2}{|c|}{ Main $\times$ Subplot Interaction } & $\mathrm{NS}^{6)}$ & NS & NS \\
\hline
\end{tabular}


Vijayakumar et al.; Enhancement of Nutritional Quality

Table 3. Changes of $\mathrm{pH}$ and organic acids on Italian ryegrass silage according to inoculation of lactic acid bacteria and chlorella

\begin{tabular}{|c|c|c|c|c|c|c|}
\hline $\mathrm{LAB}^{1)}$ & $\mathrm{CA}^{4)}$ Con. & $\mathrm{pH}$ & $\begin{array}{l}\text { Lactic acid } \\
(\mathrm{DM} \%)\end{array}$ & $\begin{array}{c}\text { Acetic acid } \\
(\mathrm{DM} \%)\end{array}$ & $\begin{array}{c}\text { Butyric acid } \\
(\mathrm{DM} \%)\end{array}$ & $\begin{array}{c}\text { Flieg's } \\
\text { score }\end{array}$ \\
\hline \multirow{3}{*}{ NON-in ${ }^{2)}$} & Control & 4.09 & 7.39 & 1.10 & 0.74 & Excellent \\
\hline & $0.25 \%$ & 4.02 & 7.78 & 0.88 & 0.16 & Excellent \\
\hline & $0.5 \%$ & 4.73 & 8.04 & 0.90 & 0.40 & Excellent \\
\hline \multirow{3}{*}{ LAB-in ${ }^{3)}$} & Control & 3.70 & 10.21 & 0.15 & 0.04 & Excellent \\
\hline & $0.25 \%$ & 3.73 & 10.25 & 0.63 & 0.08 & Excellent \\
\hline & $0.5 \%$ & 3.80 & 10.21 & 0.55 & 0.05 & Excellent \\
\hline \multicolumn{7}{|c|}{ Main effect } \\
\hline \multicolumn{2}{|c|}{ NON-IN } & 4.28 & 7.74 & 0.96 & 0.43 & \\
\hline \multicolumn{2}{|c|}{ LAB-IN } & 3.74 & 10.22 & 0.44 & 0.06 & \\
\hline \multicolumn{7}{|c|}{ Subplot effect } \\
\hline \multicolumn{2}{|c|}{ Control } & 3.90 & 8.80 & 0.63 & 0.39 & \\
\hline \multicolumn{2}{|c|}{ Chlorella $0.25 \%$} & 3.88 & 9.02 & 0.76 & 0.12 & \\
\hline \multicolumn{2}{|c|}{ Chlorella $0.5 \%$} & 4.27 & 9.13 & 0.73 & 0.23 & \\
\hline \multicolumn{2}{|c|}{ Main $\times$ Subplot Interaction } & $\mathrm{NS}^{5)}$ & NS & NS & NS & \\
\hline
\end{tabular}

1) NON-in: Non-inoculation of lactic acid bacteria, ${ }^{2)}$ LAB-in: Inoculation of lactic acid bacteria, ${ }^{3)} \mathrm{CA}$ : chlorella additive,

${ }^{4)} \mathrm{NS}$ : not significant difference.

The $\mathrm{pH}$ of IRG silage and their fermentative acid such as lactic acid, acetic acid and butyric acid production was presented in the Table 3. Chlorella supplementation along with $\mathrm{LAB}$ inoculation slightly elevated the $\mathrm{pH}$ of silage as compared with control. Lactic acid production was slightly higher in the chlorella alone and chlorella along with LAB inoculation as compared with control. The $\mathrm{pH}$ of the silage slightly increased in $0.5 \%$ chlorella alone supplemented silage as compared with control. The content of lactic acid in treatments of supplementation of two different concentration of chlorella and inoculation of LAB increased as compared with control. Among these acids, the maximum amount of lactic acid was produced by acetic acid and butyric acid.

\section{DISCUSSION}

Conserved forage indicates the major portion of diets for the ruminant and ensiling process offers an effective method of silage preservation. In the developing countries, the ruminant livestock sector is an important growing segment among the agriculture economy. Availability of forage base is a physiological priority for ruminants and economically important for the formers. Forage production is a seasonal in many parts of the world surplus available during the harvest time and deficient during winter or dry season. Generally, silages are very stable for a long time (Weinberg and Muck, 1996). Maintaining of nutritional values of silages during the storage period is important for ensiling process (Oude Elferink et al., 2000). The most important of silage is to prevent the undesired microbial activity because it spoils the nutritional quality of silage which can affect individual herd as well as fundamental implications for overall profitability. Therefore, LAB inoculation to the silage can improve the quality and stability of the silage for a long time (McDonald et al., 1991ab). In present study, we investigate the inoculation of LAB and the supplementation of chlorella as a supplement for IRG mediated silage preparation, because chlorella provides a rich protein which is provide rich nutrition for ruminants and also IRG is an easily cultivable in Korea climate and also low cost. Therefore, we prepared the IRG mediated silage by ensiling method. Chlorella supplementation and $\mathrm{LAB}$ inoculation significantly improve the content of crude protein as compared with control silage. In chlorella treated silage, the contents of $\mathrm{ADF}, \mathrm{NDF}, \mathrm{TDN}$ and IVDMD contents are similar as a control. Microbial activity 
such as LAB, yeast and fungi were analyzed, this result shows the addition of chlorella improve the LAB counts as compared with control silage. Minimum amount of yeast was recorded in the chlorella supplemented silage, but no fungi growth was observed in the silage.

The decline of the $\mathrm{pH}$ values inhibits the spoilage microorganism proliferation which preserves the quality of silage for a long time; the best silage forages are the ones with high soluble carbohydrate contents because of it promotes the fermentation and produces enough acid to preserve the silage. The minimum soluble carbohydrate contents recommended ensuring the enough fermentation of good silage (Ferreira, 2007). Present study, reduced the $\mathrm{pH}$ of the prepared silage after addition of LAB and chlorella as a supplement and increased the lactic acid production. Lactic acid production was dominant followed by acetic acid and butyric acid in the silage as compared with control. This is an important criterion for silage preparation because inhibition of undesired microbes is based on the fermentative acid production.

\section{CONCLUSION}

Improvement of nutritive values and reduction of undesired microbial growth in the silage is an added advantage for provides quality silage with good nutritional values. In this study, the nutritional values and quality were improved and the undesirable microbial growth was inhibited by additions of LAB and chlorella. Therefore, we suggest that inoculation of LAB along with different concentration of chlorella significantly improve the quality of silage.

\section{ACKNOWLEDGMENTS}

This work was carried out with the support of "Cooperative Research Program for Agriculture Science \& Technology Development (Project title: Enhancement of nutrients in silage and development of technology for improvement of silage quality; Project No. PJ008502)" Rural Development Administration, Republic of Korea.

\section{REFERENCES}

AOAC. 1990. Official methods of analysis $\left(15^{\text {th }}\right.$ ed.). Association of analytical chemisits, Washington, DC.

Chisti, Y. 2007. Biodiesel from microalgae. Biotechnology Advances. 25:294-306.

Ferreira, D.A., Gonçalves, L.C., Molina, L.R., Castro Neto, A.G. and Tomich, T.R. 2007. Caracteristicas de fermentação da silagem de cana-de-açúcar tratada com uréia, zeólita, inoculante bacteriano e inoculante bacteriano/enzimático. Arquivo Brasileiro de Medicina Veterinária e Zootecnia. 59:423-433.

Kristensen, N.B., Storm, A., Raun, B.M.L., Røjen, B.A. and Harmon, D.L. 2007. Metabolism of silage alcohols in lactating dairy cows. Journal of Dairy Science. 90:1364-1377.

Mata, T.M., Cardoso, N., Ornelas, M., Neves, S. and Caetano, N.S., 2010. Sustainable production of biodiesel from tallow, lard and poultry fat and its quality evaluation. Chemical Engineering Transactions. 19:13-18.

McDonald, P., Henderson, A.R. and Heron, S.J.E. 1991a. The Biochem istry of Silage. Chalcombe Publications, Marlow, Buckinghamshire, Bucks, UK.

McDonald, P.J., Henderson, A.R., Heron, S.J.E. 1991b. The biochemistry of silage (2 $2^{\mathrm{a}} \mathrm{Ed}$.) Mallow Chalcombe publications, ISBN 0948617225.

Miller, T.L. and Wolin, M.J. 1974. A serum bottle modification of the Hungate technique for cultivating obligate anaerobes. Applied Microbiol. 27:985-987.

Moore, J.E. 1970. Procedure for the two-stage in vitro digestion of forage. Univ. of Florida, Department of Animal Science.

Oude, E.S.J.W.H., Driehuis, F., Gottschal, J.C. and Spoilstra, S.F. 2000. Silage fermentation processes and their manipulation. FAO Electronic Conference on Tropical Silage. 1-28.

Van Soest, P.J. 1993. Cell wall matrix interactions and degradation--session synopsis. 3 In H.G. Jung, D.R. Buxton, R.D. Hatfield, and J. Ralph eds. Forage Cell Wall Structure and Digestibility. American Soc. Agronomy, Madison, W. 77-395.

Weinberg, Z.G. and Muck, R.E. 1996. New trends and opportunities in the development and use of inoculants for silage. FEMS Microbiological Review. 19:53-68.

Woolford, M.K. 1984. The silage fermentation. Marcel Dekker, ISBN 0824770390, New York.

Weinberg, Z.G. 2003. Effect of Lactic acid Bacteria on animal performance. Indian Journal of Biotechnology. 2:378-381

(Received August 13, 2014 / Revised September 16, 2014 / Accepted September 19, 2014) 